\title{
Assessing the effectiveness of protecting reserves for nature assets in China
}

\author{
WEI Dongying ${ }^{1}$, "LUO Zunlan², LI Junsheng ${ }^{2}$, WANG Wei², ZHANG Mengmeng ${ }^{1}$ \\ 1. School of Geography, Beijing Normal University, Beijing 100875, China; \\ 2. Chinese Research Academy of Environmental Sciences, Beijing 100012, China
}

\begin{abstract}
Evaluating the effectiveness of protecting nature assets is a vital component of responsive, pro-active management of protected areas. It is important to protect reserves of geological (including fossils) assets as a means to also protect national and natural heritage. At the end of 2013, 2669 protected areas had been established in China and 123 of them are reserves for nature assets. This paper builds an evaluation framework for protection effectiveness of these assets. The current elements and characteristics for effective protection are analyzed, along with an analysis of existing problems so as to construct a scientific approach to protect these assets. The influencing elements and characteristics for effective protection of nature asset reserves are included in an index evaluation system for effective protection in such areas, which contains four parts-target layer, evaluation criteria, evaluation indexes, and evaluation parameters-based on related documents and files. For the target layer, it includes nature asset evaluation and management evaluation. In the end, it is discussed how to build a comprehensive evaluation model and achieve an effective quantitative evaluation.
\end{abstract}

Keywords: nature asset reserve; evaluation of protection effectiveness; geological assets; framework

\section{Introduction}

Establishing reserves is an important means to protect natural resources and preserve biodiversity, and natural features help us to understand the history of the earth and its diversity of organisms. While establishing nature reserves is important, it is also important to evaluate the effectiveness of protection and management of such reserves. Evaluation is only worth doing if it leads to improved management of protected areas. Appropriate, targeted communication to a range of audiences is critical, as is timely feedback to those who have contributed time and information to the assessment. Public reporting of results should balance the desire for increased transparency with political sensitivities. At the local, regional, and global levels, results can be used to adapt to plans and practices, adjust resource allocations,

Received: 2014-03-31 Accepted: 2014-06-09

Foundation: Public Projects of Environmental Protection, No.201209028; National Evaluation Standard of Environment Protection Program, No.2011-27; National Natural Science Foundation of China, No.41401632

Author: Wei Dongying (1976-), PhD, specialized in park management, geography education and environment interpretation. E-mail: weidy@bnu.edu.cn

"Corresponding author: Luo Zunlan (1979-), Associate Professor, specialized in nature reserves' assessment and management. E-mail: luozunlan@163.com 
revise policies, and affirm good work.

The International Union for Conservation of Nature - The World Commission on Protected Areas (IUCN-WCPA) Management Effectiveness Evaluation Framework is a system to design evaluations for management effectiveness of protected areas based around six elements-context, planning, inputs, processes, outputs, and outcomes. The WCPA evaluation framework and the concerns of managers of protected areas are similar, and the framework is widely used to evaluate the management effectiveness of the world's protected areas. It is not a methodology, but rather a guide to developing assessment systems.

In addition, the rapid assessment of protected areas management and priority (RAPPAM) method is more polpular, and it is mainly disseminated by holding participatory workshops that include protected area managers, policy makers, and other stakeholders. The method is based on a Rapid Assessment Questionnaire to evaluate protected areas, and analyze the results to determine priorities and develop relevant conservation strategies.

\section{Current status of protecting nature reserves}

Establishing nature reserves is an effective method to protect the environment and natural resources, which also helps to protect biodiversity and accelerate economic development and achieve sustainable development. Nature reserves have become an important aspect of environmental protection in many countries and have drawn a great deal of attention from both the government and the public, including the Chinese government. For many years, construction of nature reserves has been a priority of the Chinese government ( $\mathrm{Li}, 1995)$.

At the end of 2013, there were 2669 nature reserves in China (Hong Kong, Macau, and Taiwan excluded), covering a total area of 149.65 million hectares, or about $15 \%$ of China's land area.

So far, an international classification standard for nature reserves has not been formulated. Under the Principle for Categories and Grades of Nature Reserves (GB/T 14529-93), China classifies its nature reserves in three categories - natural ecosystem reserves, wildlife reserves, and nature asset reserves. Each of the three categories can be further divided for a total of nine types. Natural ecosystem reserves include five types, forest ecosystem, grassland and meadow ecosystem, desert ecosystem, inland wetland and aquatic ecosystem, and marine and coastal ecosystem. Wildlife reserves include wild animal and wild plant reserves. Nature asset reserves include geological reserves and paleontological reserves, both of which are under management for "strict nature asset reserves" in accordance with Regulations on Natural Relic Reserve of the People's Republic of China (issued in 1994).

A nature asset reserve is one that holds special significance for mainly geological and paleontological features. China, with a long geological history, vast territory, and complicated geological structures, has abundant nature assets which are scarce and worth protecting. The first batch of nature asset reserves in China was established in 1980, including a geological reserve and a paleontological reserve (Fang et al., 1998).

Geological reserves are mainly established to protect special geological structures, geological sections, special geological landscapes, rare minerals, springs, waterfalls, and geological disaster sites, etc. Paleontological reserves are established mainly to protect fossils of ancient humans and other organisms and evidence of their activities.

Among the 2669 nature reserves in China, 123 (4.7\%) are nature asset reserves, of which 
91 are geological and 32 are paleontological. And of these 123, 21 are at the national level, of which 14 are geological and 7 are paleontological (Table 1 and Figure 1).

Table 1 National geological asset reserves and paleontological asset reserves in China

\begin{tabular}{|c|c|c|c|c|c|c|}
\hline Category & $\begin{array}{l}\text { Num- } \\
\text { ber }\end{array}$ & Name & $\begin{array}{l}\text { Administrative } \\
\text { region }\end{array}$ & $\begin{array}{l}\text { Area } \\
\left(\mathrm{hm}^{2}\right)\end{array}$ & $\begin{array}{l}\text { Main protection } \\
\text { objective }\end{array}$ & $\begin{array}{l}\text { Establishment } \\
\text { date }\end{array}$ \\
\hline \multirow{14}{*}{$\begin{array}{l}\text { Geo- } \\
\text { logical } \\
\text { asset } \\
\text { reserves }\end{array}$} & 1 & $\begin{array}{l}\text { Geologic sector of } \\
\text { Middle/Upper Pro- } \\
\text { terozoic in Jixian } \\
\text { County }\end{array}$ & $\begin{array}{l}\text { Jixian County, Tian- } \\
\text { jin }\end{array}$ & 900 & $\begin{array}{l}\text { Geologic sector of Mid- } \\
\text { dle/Upper Proterozoic }\end{array}$ & $\begin{array}{l}\text { October } 18, \\
1984\end{array}$ \\
\hline & 2 & $\begin{array}{l}\text { Geological assets in } \\
\text { Liujiang Basin }\end{array}$ & $\begin{array}{l}\text { Funing County, } \\
\text { Hebei province }\end{array}$ & 1395 & Geological assets & May 1, 1999 \\
\hline & 3 & Nihewan & $\begin{array}{l}\text { Yangyuan County, } \\
\text { Hebei province }\end{array}$ & 1015 & $\begin{array}{l}\text { Sedimentary formation of } \\
\text { Cenozoic Era }\end{array}$ & $\begin{array}{l}\text { February 18, } \\
1997\end{array}$ \\
\hline & 4 & $\begin{array}{l}\text { Seashore landscape of } \\
\text { Chengshantou }\end{array}$ & $\begin{array}{l}\text { Jinzhou District, } \\
\text { Dalian, Liaoning } \\
\text { province }\end{array}$ & 1350 & $\begin{array}{l}\text { Geological relics and } \\
\text { seashore karst landscape }\end{array}$ & April 1, 1989 \\
\hline & 5 & $\begin{array}{l}\text { Volcanic cluster of } \\
\text { Yitong }\end{array}$ & $\begin{array}{l}\text { Yitong Manchu } \\
\text { Autonomous Region, } \\
\text { Jilin province }\end{array}$ & 765 & Volcanic geological assets & $\begin{array}{l}\text { October 22, } \\
1983\end{array}$ \\
\hline & 6 & Dabusu & $\begin{array}{l}\text { Qianan County, Jilin } \\
\text { province }\end{array}$ & 11000 & $\begin{array}{l}\text { Nilin, fossils and wetland } \\
\text { ecosystem }\end{array}$ & $\begin{array}{l}\text { January } 1, \\
1993\end{array}$ \\
\hline & 7 & Five Lotus Ponds & $\begin{array}{l}\text { Wudalianchi, } \\
\text { Heilongjiang prov- } \\
\text { ince }\end{array}$ & $\begin{array}{c}10080 \\
0\end{array}$ & $\begin{array}{l}\text { Volcanic geological assets } \\
\text { and source of mineral } \\
\text { water }\end{array}$ & $\begin{array}{l}\text { March 29, } \\
1980\end{array}$ \\
\hline & 8 & $\begin{array}{l}\text { Geological assets of } \\
\text { Changxing }\end{array}$ & $\begin{array}{l}\text { Changxing County, } \\
\text { Zhejiang province }\end{array}$ & 275 & $\begin{array}{l}\text { Limestone geologic sector } \\
\text { of Permian Period }\end{array}$ & $\begin{array}{l}\text { March 14, } \\
1980\end{array}$ \\
\hline & 9 & Mashan Mountain & $\begin{array}{l}\text { Jimo, Shandong } \\
\text { province }\end{array}$ & 774 & $\begin{array}{l}\text { Geological assets such as } \\
\text { stone pillars with joints, } \\
\text { silicified wood, etc }\end{array}$ & $\begin{array}{l}\text { January } 13, \\
1993\end{array}$ \\
\hline & 10 & Danxia Mountain & $\begin{array}{l}\text { Renhua County, } \\
\text { Guangdong province }\end{array}$ & 28000 & "Danxia" landform & $\begin{array}{l}\text { November 6, } \\
1995\end{array}$ \\
\hline & 11 & $\begin{array}{l}\text { Jingyu G Qingshan } \\
\text { Mountain age }\end{array}$ & $\begin{array}{l}\text { Jingyu County, } \\
\text { Jilin province }\end{array}$ & 42325 & Geological assets & $\begin{array}{l}\text { November } 1, \\
2002\end{array}$ \\
\hline & 12 & Qingshan Mountain & Hexigten Qi & 9200 & Moulins & $\begin{array}{l}\text { December 25, } \\
2013\end{array}$ \\
\hline & 13 & Huoshizhai & Xiji County, Ningxia & 9795 & Danxia landform & January 21,2013 \\
\hline & 14 & $\begin{array}{l}\text { Siping Mountain gate } \\
\text { Mesozoic volcano }\end{array}$ & $\begin{array}{l}\text { Siping County, Jilin } \\
\text { province }\end{array}$ & 123 & $\begin{array}{l}\text { Volcanic geological } \\
\text { heritage }\end{array}$ & $\begin{array}{l}\text { December 25, } \\
2013\end{array}$ \\
\hline \multirow{7}{*}{$\begin{array}{l}\text { Paleo- } \\
\text { ntolo- } \\
\text { gical } \\
\text { asset } \\
\text { reserves }\end{array}$} & 1 & $\begin{array}{l}\text { Ancient seashore and } \\
\text { wetland }\end{array}$ & Tianjin & 35913 & $\begin{array}{l}\text { Shell bank, ancient sea- } \\
\text { shore relic of oyster beach }\end{array}$ & $\begin{array}{l}\text { December 1, } \\
1984\end{array}$ \\
\hline & 2 & $\begin{array}{l}\text { Otogosaurus fossil } \\
\text { relic }\end{array}$ & Etuoke Qi & 46410 & Dinosaur footmark fossil & $\begin{array}{l}\text { January } 1, \\
1998\end{array}$ \\
\hline & 3 & Beipiao Bird fossil & $\begin{array}{l}\text { Beipiao, Liaoning } \\
\text { province }\end{array}$ & 4630 & $\begin{array}{l}\text { Bird fossil of late Middle } \\
\text { Proterozoic, etc., ancient } \\
\text { organism fossil cluster }\end{array}$ & May 18, 1997 \\
\hline & 4 & $\begin{array}{l}\text { Shenhu Bay ancient } \\
\text { forest relics on seabed }\end{array}$ & $\begin{array}{l}\text { Jinjiang, Fujian } \\
\text { province }\end{array}$ & 3100 & $\begin{array}{l}\text { Ancient forest assets on } \\
\text { seabed, oyster beach rock } \\
\text { and geological landscape }\end{array}$ & $\begin{array}{l}\text { October 9, } \\
1991\end{array}$ \\
\hline & 5 & $\begin{array}{l}\text { Fossils of ancient } \\
\text { organisms in Shanwang }\end{array}$ & $\begin{array}{l}\text { Linqu County, } \\
\text { Shandong province }\end{array}$ & 120 & $\begin{array}{l}\text { Fossils of ancient organ- } \\
\text { isms }\end{array}$ & $\begin{array}{l}\text { January } 17, \\
1980\end{array}$ \\
\hline & 6 & $\begin{array}{l}\text { Fossil cluster of dino- } \\
\text { saur eggs in Nanyang }\end{array}$ & $\begin{array}{l}\text { Nanyang, Henan } \\
\text { province }\end{array}$ & 78015 & Fossils of dinosaur eggs & $\begin{array}{l}\text { January } 1, \\
1998\end{array}$ \\
\hline & 7 & $\begin{array}{l}\text { Fossil cluster of dino- } \\
\text { saur eggs in Qin- } \\
\text { glongshan Mountain }\end{array}$ & $\begin{array}{l}\text { Yunxian County, } \\
\text { Hubei province }\end{array}$ & 205 & Fossils of dinosaur eggs & $\begin{array}{l}\text { January 13, } \\
1997\end{array}$ \\
\hline
\end{tabular}


The nature asset reserves were established in China as early as 1980, and during the following 30 years, although under strict protection of the government, they still faced underlying threats. First, to attract tourists, irrelevant objects and man-made structures were installed that caused severe damage. Second, commercial activities such as restaurants, which focused on profits instead of environmental protection, caused pollution of environment and made damage. Third, geological sites that are prone to erosion from natural forces were not sufficiently protected. Fourth, tourists caused loss or damage of geological assets.

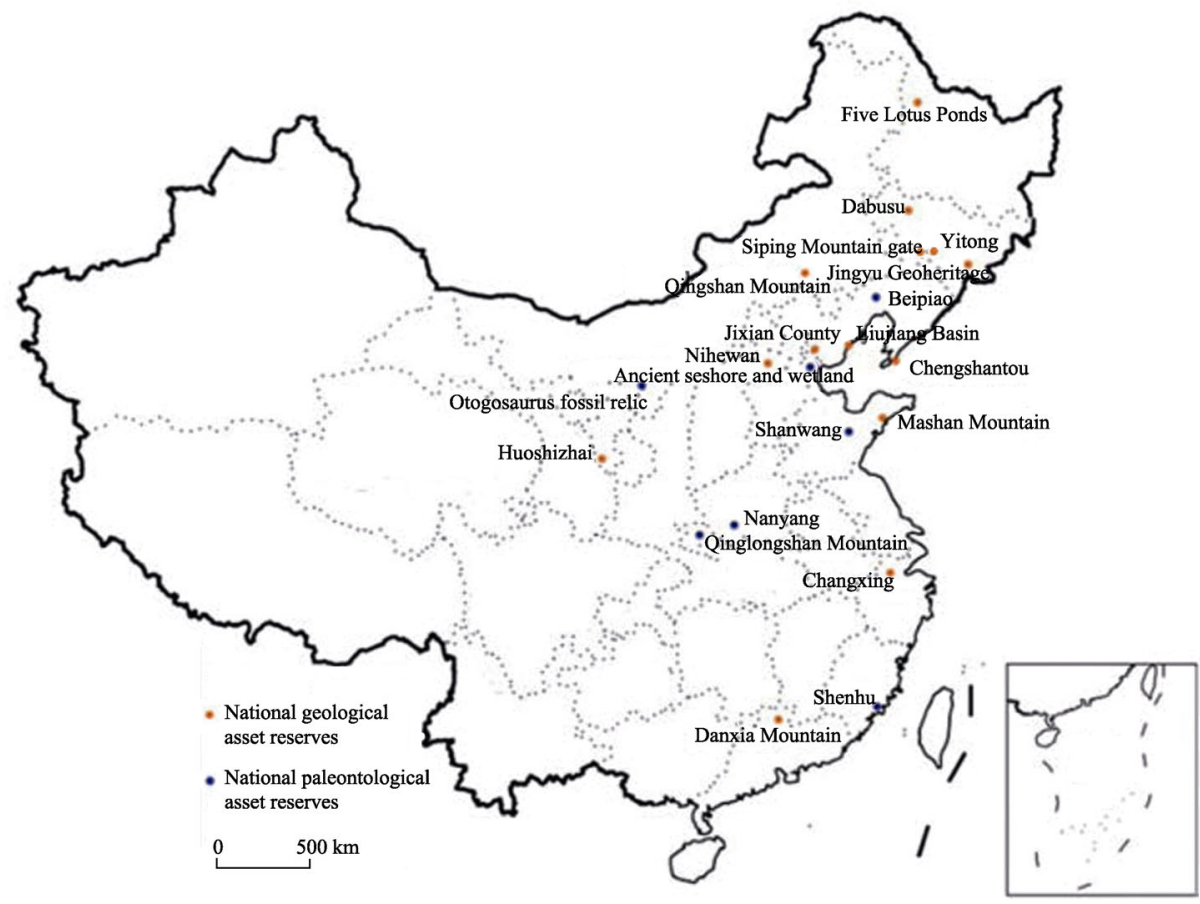

Figure 1 Distribution of national nature asset reserves in China

\section{Progress towards evaluating protection effectiveness for nature asset reserves}

\subsection{Foreign research progress}

Paleontological asset reserves are fewer in number and not as widely distributed as geological asset reserves, thus the research is mainly concentrated on the latter. In the mid-1970s, the Natural Conservancy Council (NCC) began a program to assess and document the most important sites for the study of geological and geomorphological heritage in Great Britain. In 1997, the Geological Conservation Review (GCR) was formally launched, making it the first project of its type in the world for systematic assessment of the entire geological heritage of a country (Neil, 2011).

In 1996, Guy Martini of France and Nickolus Zoulos of Greece were the first to suggest that preserving geological assets can be served by establishing geoparks. They emphasized that tourism development can promote protection of geological sites and that their protection may in return further the development of tourism. Many countries and regions of the world attached importance to such protection. Developed countries such as the United States, Can- 
Canada, and Great Britain are leaders in protection and management of geological assets. Through relevant laws and regulations, they have launched a series of protection actions.

Jamison Ervin summarized the results from implementation of the Rapid Assessment and Prioritization of Protected Area Management (RAPPAM) method in South Africa, Bhutan, China, and Russia; studied threats and pressure in the reserves; and suggested five management issues that influence the effectiveness of protected area management - funding, staffing, research and monitoring, resource inventories, and community relations (Jamison, 2003).

Nikolaus Zouros presented the current situation in terms of identifying monumental geosites in the broader Aegean area. His evaluation process was based on six criteria: (i) scientific and educational value (integrity, rarity, representativeness, and uniqueness); (ii) natural beauty and aesthetic value; (iii) cultural interest; (iv) geodiversity; (v) potential threats and protection needs (legal protection, vulnerability); and (vi) potential for use (recognition, geographical distribution, accessibility, and potential for generating economic activities) (Nikolaus, 2005).

Davide Geneletti and Iris van Duren applied multi-criteria decision analysis techniques in a spatial context to support zoning of the Paneveggio-Pale di S. Martino Natural Park, which ranged from strict nature conservation to promotion of tourism and recreation. A GIS-based land suitability analysis was carried out for each protection level, and an approach that is scientifically sound and practical has been suggested to park management and other stakeholders in Italy (Davide et al., 2008).

R. Pena dos Reis and his colleagues showed how geological heritage can be evaluated using an open system of values or content displayed by geological objects. Content is designated as indicative, documental, iconic, symbolic, scenic, and conceptual. Content is ranked in three categories of increasing importance. This open system of evaluation provided a way to evaluate the effectiveness of protection of geological assets in Portugal (Pena et al., 2009).

Charlampos Fassoulas believed that a quantitative methodology to assess geotopes may be conducive for sustainable management and conservation of geological heritage. His proposal is based on a series of criteria that cover not only the geological and geographical importance of a geotope, but also its scientific, ecological, cultural, aesthetic, and economic significance. Based on these criteria, the resulting use scores for each geotope are used to estimate the need for tourism, education, and protection value indexes for each geotope on a scale ranging from 1 to 10 in Greece (Charlampos, 2011).

Effective protection for nature asset reserves has drawn worldwide attention. Various efforts have, to some extent, promoted successful protection for such assets and demonstrated the need to evaluate the protection effectiveness for geological assets in China. To date, however, a unified evaluation system has not been created.

\subsection{Domestic research progress}

Domestic research on protection of geological assets is centered on current problems and creating solutions. Qian Jinping studied problems that emerged in the process of geological heritage protection based on a case study of geological heritage in Hebei Province. He believed that the main problems included the lack of definite management rights, the struggle 
between development and protection, and the lack of urgency to protect geological heritage. He suggested an optimal protection method for geological asset reserves (Qian, 2001). Li Xiaoqin and Qin Jianxiong suggested a protection approach based on the current status of Longmenshan Geopark in Sichuan province (Li et al., 2004). Fang Wei analyzed the characteristics and value of Mount Huang geological heritage in Anhui province, and its rare granite peak forest and glacial features of the Quaternary period. He suggested specific planning objectives, content planning, and legislative guarantees to implement the planning for Mount Huang geological asset protection (Fang, 2004).

Wu Chengji and his colleagues concerned with problems about construction of national Geoparks in China, they put forward the main task of national Geoparks and discussed the conflicts between protection and utilization, all based on a case study of protection for Cuihuashan geological heritage (Wu et al., 2004).

Zhang Yanfang discussed the importance of establishing nature reserves, and based on the current legislative deficiency, suggested a new legislative system for nature reserves (including geological assets), and improving education about protecting nature reserves so that people better understand their importance (Zhang, 2005).

Huang Song analyzed problems that emerged in the development of geological asset reserves and suggested a six-step approach for their protection - categorization, form of protection, mode of protection, level of protection, sequence of protection, and protection zoning (Huang, 2006).

$\mathrm{Hu}$ Weixia and $\mathrm{Wu}$ Chengji discussed problems that emerged during the rapid development of geoparks and suggested solutions (Hu et al., 2007). Li Xiaoqin and Lu Zhiming compared the "Danxia" landform of Ranmen Pass Geopark and the typical "Danxia" landform of Mount Danxia in Guangdong province, and created a protection plan for Ranmen Pass Geopark, as well as tactics and approaches to improve legislation, management reforms, interpretation systems, and geological ecosystems (Li et al., 2007).

Methods to assess geological heritage vary widely. Relevant documents issued by the Ministry of Land and Resources on an assessment index mainly focus on the natural attributes, protection, and the basis for protection management. Technological Requirements and Guidelines for the Construction of National Geoparks in China includes five factors for natural attributes (representativeness, rarity, naturalness, systematicness, and integrity); three factors for "protective" attributes (appropriateness of area, economic and social value, and scientific value); and five factors for the basis of protection management (personnel, borders, land ownership, basic facilities, and management). Compared with other contents of the evaluation, the evaluation of protection effectiveness is insufficient and the evaluation system is incomplete.

Hao Junqing and her colleagues, with a case study of loess geological heritage in Luochuan, suggested an evaluation system to assess current status (including scientific evaluation, integrity, and aesthetic value), protection management (including protection funds, protection planning, and management expertise), and environmental protection (including landslides and returning reclaimed land to grassland or forests) (Hao et al., 2004). The effectiveness of protecting loess in Luochuan was evaluated at good level as a case study.

An Guangrong and his colleagues used the same method and evaluated the protection ef- 
fectiveness of a "Danxia" landform of Wucai Bay area in Fuyun County in Xinjiang Uygur Autonomous Region with the same result as that of Luochuan (An et al., 2010). On the basis of previous research, Peng Yongxiang and his colleagues selected seven representative elements - protection management mechanisms, current protection status, level of difficulty for protection, protection planning, protection management actions, influence of development and human activities, and categorized the level of compromise between protection and use of geological asset resources by experts' graded approach (Peng et al., 2006). However, Shen Jian and his colleagues simplified these seven elements to four categories - current protection status, protection management, level of difficulty, and human activities. Current protection status includes scientific evaluation, integrity, and aesthetic value; protection management includes protection funds, protection planning, and management mechanism, and each of the elements is further divided into three grades for further evaluation (Shen et al., 2009).

On the whole, these evaluation systems are not specific enough to comprehensively reflect protection effectiveness for nature assets. A more comprehensive evaluation system is necessary to meet the urgent demand and influence this field.

\section{Creating an effective evaluation system to protect nature asset reserves}

\subsection{Index selection}

A crucial step to evaluate protection effectiveness for nature asset reserves is to establish an index. According to the principles of scientific integrity, representativeness, measurability, comparability, and operability, the index system of evaluating protection effectiveness of nature asset reserves was selected based on the provisions of the relevant conventions and the domestic and foreign documents as well as the characteristics of the nature asset reserves. The evaluation index has four layers, target layer, evaluation criteria, evaluation indexes, evaluation parameters. The target layer includes nature asset evaluation and management evaluation (Table 2).

\subsection{Creating an evaluation index system}

An evaluation index reflects one characteristic, defines the characteristic, and demonstrates its quantity, and thus has both qualitative and quantitative functions. Through the comprehensive evaluation of the current status and management of the nature asset in a protected area, protection effectiveness of the structure and the spatial distribution, current status and problems of the nature assets can be understood and provide the basis for effective protection.

\subsubsection{Evaluation of nature assets}

A comprehensive evaluation of the current protection for nature assets are mainly based on integrity and threats. Two indexes for degree of integrity were selected - overall integrity and stability of natural heritage. For threats, human disturbance and natural causes are main concerns. Ratio changes of the core area to the total natural heritage area is an important indicator used to evaluate integrity. Character changes of important assets in the conservation area are obtained by comparing data from different periods. These are very important 
Table 2 Evaluation index for protection effectiveness of nature asset reserves

\begin{tabular}{|c|c|c|c|}
\hline Target layer & $\begin{array}{l}\text { Evaluation } \\
\text { criteria }\end{array}$ & Evaluation indexes & Evaluation parameters \\
\hline \multirow[t]{5}{*}{$\begin{array}{l}\text { Nature asset } \\
\text { evaluation }\end{array}$} & \multirow[t]{3}{*}{$\begin{array}{l}\text { Integrity degrees } \\
\text { of nature assets }\end{array}$} & $\begin{array}{l}\text { Overall integrity of nature } \\
\text { heritage }\end{array}$ & $\begin{array}{l}\text { Area ratio changes of the core area to the } \\
\text { total natural heritage }(\%) ;\end{array}$ \\
\hline & & & Character changes of important assets; \\
\hline & & $\begin{array}{l}\text { Overall stability of nature } \\
\text { heritage }\end{array}$ & $\begin{array}{l}\text { Variation of diversity; } \\
\text { Stability of geological environment; }\end{array}$ \\
\hline & \multirow[t]{2}{*}{$\begin{array}{l}\text { Threats to nature } \\
\text { assets }\end{array}$} & Human disturbance & $\begin{array}{l}\text { Impact of large-scale human activities; } \\
\text { Impact of tourism activities; } \\
\text { Theft and destruction of important assets; }\end{array}$ \\
\hline & & Natural causes & Weathering and geological disasters; \\
\hline \multirow[t]{23}{*}{$\begin{array}{l}\text { Management } \\
\text { evaluation }\end{array}$} & \multirow[t]{5}{*}{ Management base } & $\begin{array}{l}\text { Mechanism and personnel } \\
\text { security in protected areas }\end{array}$ & $\begin{array}{l}\text { Whether allocated mechanism and person- } \\
\text { nel meet the management requirements; }\end{array}$ \\
\hline & & $\begin{array}{l}\text { Borders and functional zoning } \\
\text { of protected areas }\end{array}$ & $\begin{array}{l}\text { Scale, borders, and ownership and func- } \\
\text { tional zoning of protected areas; }\end{array}$ \\
\hline & & Infrastructure & Allocation status of infrastructures; \\
\hline & & Funding security & $\begin{array}{l}\text { Whether funding meets requirements of } \\
\text { wages, welfare, and management; }\end{array}$ \\
\hline & & $\begin{array}{l}\text { Professional technological } \\
\text { ability }\end{array}$ & Training status of professionals; \\
\hline & \multirow{6}{*}{$\begin{array}{l}\text { Management } \\
\text { mechanism }\end{array}$} & Management system & Implementation of management system; \\
\hline & & Community participation & $\begin{array}{l}\text { Suggestions made by residents and their } \\
\text { influence on decision making by the gov- } \\
\text { ernment; }\end{array}$ \\
\hline & & Monitoring and evaluation & Whether management has made progress; \\
\hline & & $\begin{array}{l}\text { Personnel management } \\
\text { (incentive mechanism) }\end{array}$ & $\begin{array}{l}\text { Formulation of management method and } \\
\text { incentive mechanisms; }\end{array}$ \\
\hline & & $\begin{array}{l}\text { Rights for administrative } \\
\text { enforcement of law }\end{array}$ & $\begin{array}{l}\text { Whether it has the rights for administrative } \\
\text { enforcement of law; }\end{array}$ \\
\hline & & $\begin{array}{l}\text { Management system in } \\
\text { protected areas }\end{array}$ & Department in charge; \\
\hline & \multirow[t]{10}{*}{$\begin{array}{l}\text { Management } \\
\text { behavior }\end{array}$} & $\begin{array}{l}\text { Planning for protection and } \\
\text { development }\end{array}$ & Implementation status of the plans; \\
\hline & & $\begin{array}{l}\text { Background research for } \\
\text { resources }\end{array}$ & Progress made by background research; \\
\hline & & Scientific research & Collaboration with scientific research; \\
\hline & & Dynamic monitoring & $\begin{array}{l}\text { Progress made by dynamic monitoring of } \\
\text { protected assets; }\end{array}$ \\
\hline & & Personnel training & $\begin{array}{l}\text { Number of staff trained and training } \\
\text { frequency; }\end{array}$ \\
\hline & & Publicity and education & Status of publicity and education; \\
\hline & & Community management & $\begin{array}{l}\text { Whether there is relevant community } \\
\text { management mechanism; }\end{array}$ \\
\hline & & Tourism management & $\begin{array}{l}\text { Control and management of tourism in } \\
\text { protected areas; }\end{array}$ \\
\hline & & Patrol in protected areas & Patrol frequency and record; \\
\hline & & Fund management & $\begin{array}{l}\text { Whether fund management and distribution } \\
\text { are rational; }\end{array}$ \\
\hline & \multirow[t]{2}{*}{$\begin{array}{l}\text { Management } \\
\text { effect }\end{array}$} & Protected area control & $\begin{array}{l}\text { Control over people outside the core and } \\
\text { buffer zone; }\end{array}$ \\
\hline & & $\begin{array}{l}\text { Coordinated development with } \\
\text { community }\end{array}$ & $\begin{array}{l}\text { Whether management activities are in con- } \\
\text { cert with development of local communities. }\end{array}$ \\
\hline
\end{tabular}


indexes to evaluate the protection effectiveness.

Aside from an overall view of how assets are protected, internal diversity and variation may also provide us with important references. For those assets whose diversity stays the same and stable, their protection has been effective. If the geological environment of a protected area is not stable enough, scientific monitoring will be carried out to locate the risk of damage, and initiate appropriate protective measures.

The effects of large-scale human activities, tourism, theft, and destruction of important assets are all problems that we faced when trying to protect assets. Should these activities be irrational, big damage may occur. If tourists misbehave or arrive in large numbers, damage may occur. People in charge of a natural attraction may focus more on commercial achievements rather than protecting assets, which has caused irreversible damage. The occurrence of theft and destruction of important assets is also important indexes to evaluate protection effectiveness. Damage may occur from weathering and geological damage. In the evaluation of threats, these indexes should be considered.

\subsubsection{Evaluation of management}

When evaluating management effectiveness, based on the RAPPAM method, the evaluation index system was made and 23 evaluation parameters were selected from management base, management mechanism, management behavior, and management effect.

Management base includes organization, personnel, funding, and facilities within the protected area. The specific parameters are mechanisms and personnel security in protected areas, borders and functional zoning of protected areas, infrastructure, funding security, and professional technological ability. These focus on whether the allocated mechanisms and personnel meet the requirements of management, scale, borders ownership, functional zoning of protected areas, allocation of infrastructure, whether funding meets the requirements of wages, and management and training of professionals. This evaluation item is the foundation of management effectiveness of nature asset reserves.

Management mechanism includes regulations, plans, goals, funding distribution, and reconciliation with local residents, neighboring residents, community and other related organizations, departments, and enterprises. These parameters include implementation of the management system, suggestions made by residents and their influence on decision making by the government, monitoring and evaluation of management effectiveness, management methods, incentive mechanisms, and whether it has the rights for administrative enforcement of laws and status of departments in charge. Perfecting a rational management mechanism is a crucial link for effective management of nature asset reserves.

Management behavior includes actions to reach a protection goal. Elements include implementation status of the plans, progress made by background research, collaboration with scientific research, progress made by dynamic monitoring of protected assets, number of staff trained and training frequency, and status of publicity and education. Also included are relevant community management mechanisms, control and management of tourism in a protected area, patrol frequency and records, and whether fund management and distribution are rational. Scientific management behavior is conducive to improving management effectiveness.

Management effect includes the condition of protected assets, management and protection conditions of protected assets, and influence on economic development of neighboring communities and regions. Also considered are control over people outside the core and 
buffer zone and whether management activities reconcile with the development of local communities.

In real evaluation, the parameters can be adjusted according to the actual situation, and the four criteria are in progressive order.

\section{Conclusions and discussion}

The research analyzed the influencing elements and characteristics for protection effectiveness of nature asset reserves and established the index system for protection effectiveness in such areas, which includes four parts - target layer, evaluation criteria, evaluation indexes, and evaluation parameters - based on related documents and files. For the target layer, it includes nature asset evaluation and management evaluation, and for the nature asset evaluation, it includes the integrity degrees of nature assets and threats to the nature assets, and for the management evaluation, it includes management base, management mechanism, management behavior and management effect.

Because the indexes serve different functions and are of different importance, each index should be weighted differently so as to build a comprehensive evaluation model and achieve an effective quantitative evaluation.

Evaluation of geological and paleontological assets mainly based on qualitative research, how to conduct a quantitative assessment of geological and paleontological assets remains a key and difficult point. Weighting each index is a critical step in the evaluation index system in the planning process. In order to ensure the results of the evaluation system scientific and accurate, the weight coefficient needs to be scientific and reasonable.

In addition, how to quantify indicators is critical to the later evaluation. Analytic hierarchy process (AHP) is a convenient, flexible and practical multi-factor weights decision scheme. The application principle of AHP in multi-level indicators to the evaluation system is divided into five steps:

- Construct the judgement matrices; using judgments to determine the ranking of the criteria;

- Establish priorities among the elements of the hierarchy by making a series of judgments based on pairwise comparisons of the elements. For example, when comparing nature asset evaluation and management evaluation, the evaluators might indicate the relative importance of one element over another;

- Synthesize these judgments to yield a set of overall priorities for the hierarchy. This would combine the evaluators' judgments into target layer, evaluation criteria, evaluation indexes, and evaluation parameters;

- Check the consistency of the judgments;

- Come to a final decision based on the results of this process.

However, AHP is a subjective weighting method, and the interference of subjective factors must be reduced in the process of weight assignment.

Case studies are also needed to prove the scientific soundness and practicability of this model and to further explain and describe the specific functions of our model. Therefore, according to needs of the research, field research need to be done in some important National Nature Asset Reserves, combined with the real situation of the reserves, the evaluation system will be revised and improved to ensure that it is scientific and effective to the whole evaluation. 


\section{References}

An G R, Chen Q, 2010. Evaluation of geological heritage protection level evaluation based on fuzzy comprehensive-Wucaiwan Fuyun County, Xinjiang Danxia geological heritage for the study. West-China Exploration, (9): 142-144. (in Chinese)

Ellis N, 2011. The Geological Conservation Review (GCR) in Great Britain: Rationale and methods. Proceedings of the Geologists' Association, 122: 353-362.

Environmental Protection Department, 2011. List of Nature and Ecology Conservation of the National Nature Reserve. Beijing: China Environmental Science Press. (in Chinese)

Eriven J, 2003. Rapid assessment of protected area management effectiveness in four countries. BioScience, 53(9): 833-841.

Fang K D, Huang M Z, 1998. The establishment of natural relic protection and natural relic reserves in China. Research of Environmental Sciences, (6): 47-51. (in Chinese)

Fang W, 2004. Conservation and planning of world geo-heritage in Mount Huangshan. Research of Soil and Water Conservation, 11(4): 206-208. (in Chinese)

Fassoulas C, Mouriki D, Dimitriou-Nikolakis P et al., 2011. Quantitative assessment of geotopes as an effective tool for geoheritage management. Geoheritage, 11: 46-53.

Geneletti D, Duren I V, 2008. Protected area zoning for conservation and use: A combination of spatial multicriteria and multiobjective evaluation. Landscape and Urban Planning, 85: 97-110.

Hao J Q, Li Y Q, Wen M, 2007. Assessment of Luochuan loess geological vestige based on fuzzy synthesis judgment. Geology of Shaanxi, 25(1): 45-50. (in Chinese)

Hao J Q, Wu C J, Tao Y K et al., 2004. Protection and utilization assessment of geological remains: A case study of the loess remains of Luochuan Mountain. Journal of Mountain Science, 22(1): 7-11. (in Chinese)

$\mathrm{Hu}$ W X, Wu C J, 2007. The characteristics of national geopark in China, some problems and study on some measures for its rapid construction. Geological Review, 53(1): 98-103. (in Chinese)

Huang S, 2006. Optimal selection mode and step of geological heritage protection: A case study of Xinjiang. Guilin University of Technology, 26(1): 148-152. (in Chinese)

Li W H, Zhao X Y, 1995. The Natural Protection in China. Beijing: The Commercial Press, 152-153, 173-174. (in Chinese)

Li X Q, Lu Z M, 2007. Study on geological relic sight protection of Jianmenguan Geopark in Sichuan. Research of Soil and Water Conservation, 14(5): 118-120. (in Chinese)

Li X Q, Qin J X, Yin J C, 2004. Protection of geological relics in Longmen Mountains National Geopark. Journal of Mountain Science, 22(1): 12-16. (in Chinese)

Liu B L, Qu J J, Niu Q H et al., 2014. Computational fluid dynamics evaluation of the effect of different city designs on the wind environment of a downwind natural heritage site. Journal of Arid Land, 6(1): 69-79.

Peng Y X, Wu C J, 2006. Evaluation on the relationship between conservation and utilization of geological relics: A case from Shanxi Province. Resource Science, 28(1): 192-197. (in Chinese)

Qian J P, 2001. Hebei geological heritage diversity conservation recommendations. Chinese Population, Resources and Environment, 11(1): 136-137. (in Chinese)

Reis R, Henriques M H, 2009. Approaching an integrated qualification and evaluation system for geological heritage. Geoheritage, 1: 1-10.

Shen J, Hao C Y, Wang H F, 2009. Accordance between utilization and protection of geoheritage in Mentougou, Beijing. Resources and Industries, 11(4): 37-41. (in Chinese)

Wu C J, Han L Y, Tao Y K et al., 2004. The coordinative operation of national geoparks based on the protection and utilization of geological remains: A case study of the national geopark of the landslide landscape, Cuihua Mountain. Journal of Mountain Science, 22(1): 17-21. (in Chinese)

Zhang Y F, 2005. The legal protection of nature reserve of geological trace. Science and Technology Progress and Policy, 22(8): 80-82. (in Chinese)

Zouros N, 2005. Assessment protection and promotion of geomorphological and geological sites in the Aegean area, Greece. Géomorphologie: Relief Processu Environment, 3: 227-234. 